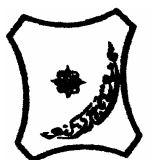

Bayero Journal of Pure and Applied Sciences, 7(2): 26-30

Received: April 2014

Accepted: October 2014

ISSN 2006 - 6996

\title{
PHYSICO-CHEMICAL, SENSORY AND MICROBIOLOGICAL QUALITIES OF YOGHURT BRANDS SOLD IN KANO METROPOLIS, NIGERIA
}

\author{
*Omola, E.M., Kawo, A.H. and Shamsudden, U., \\ Department of Microbiology, Faculty of Science, Bayero University, Kano Nigeria \\ Correspondence author: omolamichael@yahoo.com
}

\begin{abstract}
This study was conducted to evaluate the physico-chemical, sensory and microbiological qualities of some yoghurt brands sold in Kano Metropolis using standard procedures. The physico-chemical characteristics (viscosity, specific gravity, pH, titratable acidity, fat content) and Sensory properties (color, flavor, smell) were determined using the method of the Association of Official Analytical Chemists. The microbiological evaluations were based on the Aerobic mesophilc bacterial, Coliform, Escherichia coli, fungal counts as well as the detection of Staphylococcus aureus and Salmonella sp. using the method of Food and Agricultural Organization and the result presented. Two of the pathogenic strains $S$. aureus and Salmonella sp. were not isolated in any of the yoghurt samples analyzed. However, mesophilic bacteria, Coliform, Escherichia coli and fungi were positive in some samples. The results of chemical analysis showed no significant differences $(p>0.05)$ between yoghurt samples. Organoleptically, sample YB5 was more significantly of better quality than the rest in terms of its color (7), its flavor (9) and had a significantly higher overall acceptability $(p<0.05)$. The microbial load of all the yoghurt samples except for yoghurt samples (YB3, YB4, YB6 and YB7) microbiologically falls within the acceptable local and international standards.
\end{abstract}

Keywords: Microbiological, Yoghurt, Physico-Chemical, Sensory evaluation, Kano - Nigeria.

\section{INTRODUCTION}

Yoghurt is a semi-solid fermented milk product which originated in Mesopotamia thousands of years ago. Evidence has shown that these people had domesticated goats and sheep around 5000 B.C. The milk from these animals was stored in gourds, and in the warm climate, it naturally formed a curd, which was an early form of yoghurt (Beel, 1994).

One legend tells that yoghurt was born by a miracle of nature. Micro-organisms of various kinds happened to land in a pitcher of milk that belonged to a Turkish nomad. The result was what the Turks called "Yogurut. The name 'yogurut' was supposedly introduced in the $8^{\text {th }}$ century and was changed in the $11^{\text {th }}$ century to the current version, yoghurt (Bylund, 1995). In the early years of milk fermentation, milk was simply allowed to ferment by its normal microbiota, but the actual process was not completely understood. Cultures could be maintained by inoculating fresh milk with fermented milk (Kerr and McHale, 2001). Today, lactic acid-producing microorganisms are added to milk to decrease the $\mathrm{pH}$ of the milk and produce many different fermented milk products (Guarner et al., 2005).

These bacteria ferment the lactose in the milk to lactic acid, causing the milk to curdle and form yoghurt. If the product is not pasteurized, the result is yoghurt with "active cultures" (Sahan et al, 2009). Lactic acid bacteria are fastidious microorganisms and their growth is often restricted in milk because of its paucity in essential nutrients, thus the success of milk fermentation relies most often upon the synergy between $S$. thermophilus and
L. bulgaricus. Because both bacteria are able to grow alone in milk, this indirect positive interaction is called proto-cooperation (Courtin and Rul, 2004).

In 1919, Isaac Carasso who was from Ottoman Salonika industrialized the production of yoghurt. While yoghurt has been around for many years, it is only recently (within the last 30-40 years) that it has become popular. Today, it plays an important role in many different world cuisines. The consistency, flavor and aroma may vary from one region to another (Fabian, 2009). This study is aimed at determining the physico-chemical, sensory and microbiological qualities of yoghurt brands sold in Kano Metropolis, Nigeria.

\section{MATERIALS AND METHODS \\ Sample collection}

One hundred (100) samples of commercially produced yoghurt were obtained from retail outlets; super markets, stores and vendors in Kano metropolis. The samples were collected on weekly basis for six months during the period (June to November 2010) and were transported to Microbiology laboratory of Bayero University Kano in an ice box.

\section{Design}

The samples which represent ten different manufacturers $\left(\mathrm{YB}_{1}, \mathrm{YB}_{2}-\mathrm{YB}_{10}\right)$ had ten samples each from each different manufacturer and were analyzed for physicochemical, sensory and microbiological qualities. Manufacturing details such as: NAFDAC number, batch number, manufacturing date, expiry date, ingredients as well as content were monitored. 


\section{Physico-chemical Analysis}

Physico-chemical analyses were carried out according to the method of the Association of Official Analytical Chemists (AOAC, 2005).

\section{Measurement of temperature and fat content}

The temperature was measured by dipping the glass thermometer into the yoghurt sample and the corresponding reading taken. The fat content was measured by butyrometer according to Gerber method (AOAC, 2005)

\section{Measurement of viscosity and specific gravity}

Viscosity was measured using a viscometer model DV$\mathrm{E}$ viscometer using a glass tube and a normalized ball equipped with a chronometer at $20^{\circ} \mathrm{C}$. Viscosity was expressed as centipoise. Specific gravity was measured using a lacto-densitometer and expressed in $\mathrm{g} / \mathrm{ml}$ (AOAC, 2005).

\section{Measurement of pH and acidity}

The $\mathrm{pH}$ of yoghurt samples was measured using labtech $\mathrm{pH}$ meter with a glass electrode.

Acidity was determined by titration with $0.1 \mathrm{~N} \mathrm{NaOH}$ using phenolphthalein as an indicator of color (AOAC, 2005).

\section{Sensory evaluation}

Sensory quality of yoghurt products was evaluated by a jury of 5 untrained panelists with a 9-point hedonic scale and involved the following parameters: color, smell, flavor and overall acceptability (Meilgaard et al.,1999). Subjects tasted the samples and were asked to keep the yoghurt in the mouth for 12 seconds before scoring. The yoghurt samples were presented in random order. Water was used for rinsing mouth between samples (International Dairy Federation, IDF, 2002).

\section{Microbiological Analyses Enumeration, isolation and characterization of bacteria and fungi}

Bacterial and fungal culturing were carried out using the pour plate technique as described by the International Dairy Federation (IDF, 2002) using nutrient agar and malt extract agar respectively. Nutrient agar plates were incubated at $30^{\circ} \mathrm{C}$ for $48 \mathrm{~h}$ for aerobic mesophilic bacterial count while malt extract agar plates were incubated at room temperature $\left(25^{\circ} \mathrm{C}\right)$ for $48-72 \mathrm{~h}$.

Coliforms were determined by the MPN method for a three tube series using lactose broth incubated at $37^{\circ} \mathrm{C}$ for $48 \mathrm{~h}$. E.coli was detected using eosin methylene blue at $35^{\circ} \mathrm{C}$ for $24 \mathrm{~h}$.

For Staphylococcal counting, Baird Parker Agar was used. Deoxychollate Citrate Agar was used for Salmonella after enrichment with selenite cystein medium.

Cultural, morphological and biochemical characterization of the bacterial isolates were carried out as described by Cheesebrough (2000) while characterization of fungal isolates was by the method of Barnett and Hunter (1972).

\section{Statistical Analysis}

The data obtained from the study were analyzed by analysis of variance (ANOVA), using single factor at $\mathrm{P}>0.05$ to provide the possibility of comparing the levels of contamination of different yoghurt brands.

\section{RESULTS}

The results of the physico-chemical and sensory qualities of the yoghurt samples are presented in Table 1 . The highest temperature was $28^{\circ} \mathrm{C}$, while the lowest was $0^{\circ} \mathrm{C}$. The viscosity ranged between 8.9 to 65.2 centipoise. The specific gravity of the yoghurt samples ranged between 1.042 and 1.063 . $\mathrm{YB}_{9}$ had the lowest specific gravity, while $\mathrm{YB}_{10}$ had the highest specific gravity. The $\mathrm{pH}$ of all the yoghurt samples analyzed fell within the range of 1.44 and 5.35. The values for titratable acidity were in the range of $4(0.38)$ to $12.8(1.22) \%$ lactic acid.

The fat content ranged from 1.5 to 2.5 with the fat contents of $\mathrm{YB}_{5}$ significantly higher than the fat content of other brands of yoghurt samples analyzed.

Sensory evaluation was carried out using a 9 - point hedonic scale with $\mathrm{YB}_{5}$ having a significantly higher overall acceptability $(p<0.05)$.

The aerobic mesophilic bacterial counts ranged between $1.9 \times 10^{2}$ and $2.2 \times 10^{5} \mathrm{cfu} / \mathrm{ml}$, a significant difference $(p<0.05)$ in bacterial count was observed between the samples with $\mathrm{YB}_{4}$ and $\mathrm{YB}_{7}$ having the highest scores. There was significant difference $(p<0.05)$ in coliform count between the samples with $\mathrm{YB}_{4}$ having the highest count. Fungal counts ranged from $8.6 \times 10^{1}$ to $2.5 \times 10^{4}$. A significant difference $(p<0.05)$ in fungal counts was observed between the samples with $\mathrm{YB}_{6}$ having the highest count. Escherichia coli was positive in $17(34) \%$ of the yoghurt samples analyzed. None of the samples for detection of Staphylococcus $s p$. and Salmonella $s p$. in all the yoghurt brands analyzed was positive. 
Table 1: Mean physico-chemical and sensory qualities of yoghurt brands sold in Kano Metropolis

\begin{tabular}{|c|c|c|c|c|c|c|c|c|c|c|}
\hline \multirow[b]{2}{*}{ Sample } & \multirow{2}{*}{$\begin{array}{l}\text { Temp } \\
\left({ }^{\circ} \mathrm{C}\right)\end{array}$} & \multirow[b]{2}{*}{$\begin{array}{c}\text { Fat Content } \\
(\%)\end{array}$} & \multicolumn{2}{|c|}{ Analysis } & \multirow[b]{2}{*}{ pH } & \multirow[b]{2}{*}{$\begin{array}{l}\text { Acidity } \\
(\%)\end{array}$} & \multirow[b]{2}{*}{ Color } & \multicolumn{2}{|c|}{ Sensory evaluation } & \multirow[b]{2}{*}{$\begin{array}{c}\text { General } \\
\text { Acceptability }\end{array}$} \\
\hline & & & $\begin{array}{c}\text { Viscosity } \\
\text { (Centipoise) }\end{array}$ & $\begin{array}{c}\text { Specific } \\
\text { gravity } \\
\text { (g/mls) }\end{array}$ & & & & Flavor & Smell & \\
\hline YB1 & 0 & 1.80 & 49.80 & 1.05 & 3.06 & 9.00 & 8 & 8 & 7 & 7 \\
\hline YB2 & 0 & 1.60 & 8.90 & 1.04 & 3.03 & 9.40 & 5 & 7 & 4 & 6 \\
\hline YB3 & 27 & 1.50 & 11.40 & 1.05 & 3.05 & 9.20 & 7 & 7 & 4 & 6 \\
\hline YB4 & 26 & 1.50 & 12.80 & 1.04 & 3.44 & 5.20 & 6 & 7 & 7 & 6 \\
\hline YB5 & 19 & 2.50 & 35.40 & 1.05 & 5.35 & 4.00 & 7 & 9 & 7 & 9 \\
\hline YB6 & 28 & 2.20 & 60.10 & 1.05 & 1.55 & 11.00 & 6 & 5 & 7 & 6 \\
\hline YB7 & 14 & 2.30 & 57.90 & 1.05 & 4.30 & 6.50 & 6 & 6 & 7 & 8 \\
\hline YB8 & 24 & 1.80 & 28.80 & 1.05 & 4.34 & 8.00 & 7 & 7 & 7 & 7 \\
\hline YB9 & 26 & 1.50 & 9.50 & 1.04 & 4.04 & 10.50 & 8 & 8 & 7 & 8 \\
\hline YB10 & 28 & 2.40 & 65.20 & 1.06 & 1.40 & 12.80 & 6 & 5 & 7 & 6 \\
\hline
\end{tabular}

KEY: $\quad Y B=$ Yoghurt Brand. $\quad$ Each value is mean of 10 determinations

Acceptability score : 1- Disliked extremely, 2- Disliked very much, 3 - Disliked moderately, 4 - Disliked slightly, 5 - Neither liked or disliked, 6 - Liked slightly, 7 - Liked moderately, 8 - Liked very much, 9 - Liked extremely

Table 2: Microbiological qualities of yoghurt effect for sale in Kano metropolis

Sample Mean-bacterial count (cfu/ml) Coliform-count (MPN/ml) E.coli.

No_(\%) contaminated

Salmonellas, aureus Fungal counts

\begin{tabular}{|c|c|c|c|c|c|c|}
\hline$\overline{\mathrm{YB}_{1}}$ & $6.4 \times 10^{2}$ & 480 & $1(2)$ & - & - & $4.2 \times 10^{3}$ \\
\hline $\mathrm{YB}_{2}$ & $8.8 \times 10^{3}$ & 485 & $1(2)$ & - & - & $5.8 \times 10^{2}$ \\
\hline $\mathrm{YB}_{3}$ & $1.1 \times 10^{5}$ & 973 & $3(6)$ & - & - & $8.7 \times 10^{2}$ \\
\hline $\mathrm{YB}_{4}$ & $2.2 \times 10^{5}$ & 980 & $3(6)$ & - & - & $2.1 \times 10^{3}$ \\
\hline $\mathrm{YB}_{5}$ & $1.9 \times 10^{2}$ & 97 & $1(2)$ & - & - & $8.6 \times 10^{1}$ \\
\hline $\mathrm{YB}_{6}$ & $2.1 \times 10^{5}$ & 966 & $2(4)$ & - & - & $2.5 \times 10^{4}$ \\
\hline $\mathrm{YB}_{7}$ & $2.2 \times 10^{5}$ & 965 & $2(4)$ & - & - & $5.2 \times 10^{2}$ \\
\hline $\mathrm{YB}_{8}$ & $5.8 \times 10^{2}$ & 9 & $1(2)$ & - & - & $4.6 \times 10^{2}$ \\
\hline $\mathrm{YB}_{9}$ & $1.2 \times 10^{3}$ & 481 & $1(2)$ & - & - & $8.0 \times 10^{2}$ \\
\hline $\mathrm{YB}_{10}$ & $1.5 \times 10^{3}$ & 5 & $1(2)$ & - & - & $1.2 \times 10^{3}$ \\
\hline
\end{tabular}

KEY: YB $=$ Yoghurt brand $(-)=$ Absent,$(+)=$ Present. $\quad$ Each value is a mean of 10 determinations 


\section{DISCUSSION}

In this study, the mean temperature was $19.3^{\circ} \mathrm{C}$ which was higher than the findings of Egwaikhide and Faremi (2010). Actual temperature of storage in markets is important for bacterial viability in yoghurts. Industrial standards recommends for yoghurts, a holding temperature not higher than $8^{\circ} \mathrm{C}$.

In this study the viscosity ranged from 8.9 to $65.2 \mathrm{cp}$, which was lower than that reported by Okoye and Animalu (2009) but comparable to that reported by Fadela et al (2009). The variation in viscosity could be attributed to the stabilizer used by individual manufacturers, the role of stabilizer in yoghurt is to bind the water and improve the texture (Imran et al., 2008). The specific gravity of the yoghurt samples collected in this study ranged from 1.042 to 1.063 which is within the International standards (1.040 1.070). The specific gravity is mainly due to the presence of water contents and small concentrations of fats, proteins, vitamins, enzymes and minerals in the sample (Imran et al., 2008). The $\mathrm{pH}$ is the parameter that determines the sample's acidity and alkalinity. The $\mathrm{pH}$ range 1.4 to 5.35 in the current study was comparable with those reported by Okoye and Animalu (2009); Egwaikhide and Faremi (2010), but lower than those reported by Eissa et al (2010). The international minimum acceptable standard for $\mathrm{pH}$ is 4.4 (FAO, 1979).

Sokolinska et al (2004), indicated that the $\mathrm{pH}$ values of milk decreased during the manufacturing process, from the time it was inoculated with bacterial cultures to the time when it was manufactured ranging from $6.7-4.3$, this is because lactic strains have the ability to ferment lactose into lactic acid with an increase in acidity and a decrease in $\mathrm{pH}$ of fermented milk. The results of the titratable acidity obtained in this study agreed with the findings of Okoye and Animalu (2009), Eissa et al ( 2010). However, it was lower than that reported by Egwaikhide and Faremi (2010). Standard range of acidity is $(0.14-0.16)$.

In this study, the mean value of fat content is $1.9 \times 10^{\circ}$ which was below that reported by Eissa et al (2010), Egwaikhide and Faremi (2010) for yoghurt brands in Kaduna Metropolis but similar to that of Shojaei and Yadollahi (2010) in Shahrekord - Iran. The decrease in the fats content of these brands of the yoghurt may be as a result of aerobic mesophilic bacteria utilizing lipids for the synthesis of cell membrane and other cellular organelles in order to increase their population. According to FAO standard, fat content of $0.5-10$ is good but fat content of 3.0 is the best. The sensory quality of the yoghurt samples was determined using the 9-point Hedonic Scale with $\mathrm{YB}_{5}$ scored significantly higher than the other brands in terms of general acceptability $(p<0.05)$. This could be due to good manufacturing practice on the part of the manufacturer. The aerobic mesophilic bacterial count ranged from $1.9 \times 10^{2}$ to $2.2 \times 10^{5} \mathrm{cfu} / \mathrm{ml}$ which were higher than the value obtained by Okoye and Animalu (2009) as well as Egwaikhide and Faremi (2010). This difference may be due to non aseptic handling and inadequate heat treatment during pasteurization process. The bacterial count should not exceed $1.0 \times 10^{5} \mathrm{cfu} / \mathrm{ml}$, the standard given by $\mathrm{FAO}(1979)$.

In the study carried out by Younus et al (2002), coliform was not detected, in any of the yoghurt samples analyzed so also the works of Birollo et al; (2001), Okoye and Animalu (2009), Ewaikhide and Faremi (2010). However, in this study coliform was observed in some yoghurt samples and the results obtained were higher than that reported by Irkin and Eren (2008). Based on standards of pasteurized milk, the coliform bacteria count must not exceed $5 \mathrm{cfu} / \mathrm{ml}$. Presence of coliforms in pasteurized milk might be from poor hygiene or cross contamination from handlers (Birollo et al.,2001).

In this research Escherichia coli, an indicator organism of fecal contamination was isolated from some yoghurt samples which concurs with previous reports ( Eissa et al., 2010 ) but was not detected in another study by Irkin and Eren (2008). The presence of Escherichia coli indicate post-pasteurization contamination of the product prior to or during packaging. Escherichia coli is commonly used as surrogate indicator and must be negative to be safe for consumers based on European union regulations. Its presence in food generally indicates direct or indirect fecal contamination. Substantial number of Escherichia coli in food suggests a general lack of cleanliness in handling and improper storage (Shojaei and Yadollahi, 2008).

In this study, Staphylococcus aureus was not detected in any of the samples. Results obtained are in agreement with the results of Egwaikhide and Faremi (2010). This could be due to the pasteurization and post pasteurization practices of manufacturers. The sample was considered safe when the count did not exceed 10cfu/ml, FAO (1979). Eissa et al (2010) reported that Salmonella species was not detected in any of the yoghurt samples studied in Khartoum Sudan. This is in agreement with this current research which could be due to addition of preservatives to prevent growth of pathogens and to prevent re-use of starter cultures of choice. The sample was considered safe when Salmonella is not detected in the food, (FAO, 1979).

In another study by Egwaikhide and Faremi (2010), fungi were not detected in any of the samples, so also the work of Birollo et al (2001). However in this research fungi were detected in some of the yoghurt samples. This is in support of the results of Irkin and Eren (2008). The presence of the organisms as contaminants may be used as indices of sanitary conditions. Their presence in yoghurt can lead to swell on packages and reduce the shelf life when levels reach $10^{5}-10^{6} \mathrm{cfu} / \mathrm{ml}$. To pass the test of safety the mould count should not exceed $1 \mathrm{cfu} / \mathrm{ml}$.

\section{CONCLUSION}

This study concludes that the yoghurt samples have good chemical quality when compared to international standards. 
However, the microbiological quality was lower than the international standard $(p<0.05)$ in some samples, although, not to the level that can compromise the health of the consumer. Proper hygiene and storage ethics should therefore be

\section{REFERENCES}

Association of Official Analytical Chemists: AOAC, (2005). Official Methods of Analysis of AOAC International. $18^{\text {th }}$ Edition, Gaithersburg, MD, United States of America.8: 8-25

Barnett, H.L and Hunter, B.B ( 1972). Illustrated Genera of Imperfect Fungi, $3^{\text {rd }}$ edition.Burgess Publishing Company, Minneapolis P 241.

Beel, B (1994). The hidden world of yoghurt. View magazine. Pp 6-19.

Birollo, G.A.; Reinheimer, G.A \& Vinderolla, C.G. (2001). Viability of lactic acid microflora in different types of yoghurt, Food Research International 33: 799-805.

Bylund, G. (1995). Diary Processing Handbook. Tetrapak Processing Systems. A.B. Lund, Sweden. Pp 213-262

Cheesbrough, M.(2000). .District Laboratory Practice in Tropical Countries, Part 2. Cambridge university press. United Kingdom. Pp 38-184

Courtin, P. and Rul, F. (2004). Interactions between microorganisms in a simple ecosystem: Yoghurt bacteria as a study model. Lait, 84: 125-134

Egwaikhide, P.A. and Faremi, A.Y. (2010). Bacteriological analysis of locally manufactured yoghurt, Electronic Journal of Environmental, Agricultural and Food Chemistry 9(11):1679-1685

Eissa, E.A, Mohammed, A, Yaqoub, E.A and Babiker, E.E, (2010). Physicochemical, microbiological and sensory characteristics of yoghurt produced from Goat milk. Electronic journal of Environmental, Agricultural and Food Chemistry 22: (8) 210-215

Fabian, E (2009) Influence of daily consumption of probiotic and conventional yoghurt in the plasma lipid profile in young healthy women, Annals of Nutrition and Metabolism 50 (4): 387-393

Fadela, C; Abderrahim, C. and Ahmed, B. (2009). "Physicochemical and rheological properties of yoghurt manufactured with Ewe's milk and skim milk".African Journal of Biotechnology 8 (9): 1938-1942.

Food and Agriculture Organization of the United Nations (FAO,1979). Manual of Food Quality Control,4. Microbiological Analysis, FAO food maintained due to the presence of microorganisms in some of the products.

These findings may be useful to the concerned governmental and health agencies to monitor the quality of yoghurt products in the market.

and nutrition paper, FAO Rome, Italy paper 14(4) : D1 - D39.

Guarner, F. G. Perdigon, G. Corthier, S. Salminen, B. Koletzko, A and Morelli. L (2005). Should yoghurt cultures be considered probiotic?. British Journal of Nutrition 93: 783-786

Imran, M, Khan, H. Shah, H. and Khan, R. (2008) Physicochemical characteristics of various milk samples available in Pakistan. Journal of Zhejiang Univ. Science B9 (7): 546 - 551

International Dairy Federation (IDF,2002). Fermented milk: Proceedings of the IDF seminar on aroma and texture of fermented milk, held in Kolding, Denmark. 301: 280-315.

Irkin, R. and Eren, U.V (2008). A research about viable Lactobacillus bulgaricus and Streptococcus thermophilus numbers in the market yoghurts. World Journal of Dairy and Food Sciences 3(1):25-28.

Kerr, T.J and McHale, B.B (2001) Applications in General Microbiology: A laboratory manual. $6^{\text {th }}$ edition, Hunter textbooks incorporated. Winston-Salem. Pp 221-230

Meilgaard, M.C: Civille, G.V. and Carr, B.T (1999). Sensory Evaluation Techniques ( ${ }^{\text {rd }}$ ed.) CRC press, LLC, U.S.A. P.416.

Okoye, J.I. and Animalu, I.L. (2009) Evaluation of physicochemical and microbiological properties of stirred yoghurt stabilized with sweet potato ( Ipomea Batata) Continental Journal of Microbiology 3:27-30.

Sahan, N. Yasar, K. Hayaloglu A.A.(2009). Physical, chemical and flavor quality of non fat yoghurt as affected by a $\beta$-glucan hydrocolloidal composite during storage. Food Hydrocolloids 22:1291-1297.

Shojaei, Z.A. and Yadollahi, A. (2010). "Physicochemical and microbiological quality of raw, pasteurized and UHT milks in Shahrekord". Journal of Diary Science 59 (2):532-538.

Sokolinska, D.C, Michalski, M.M, and Pikul, J (2004). Role of the proportion of yoghurt bacterial strains in milk souring and the formation of curd qualitative characteristics. Bulletin of Veterinary Institute Pulawy 48:437-441.

Younus, S.T. Masud. K and Aziz, T. (2002). Quality Evaluation of Market Yoghurt / Dahi, Pakistan Journal of Nutrition 1(1): 226-230. 